\title{
Human papillomavirus 16 infection as a potential risk factor for prostate cancer: an adaptive meta-analysis
}

\author{
Jong-Myon Bae \\ Department of Preventive Medicine, Jeju National University School of Medicine, Jeju, Korea
}

\begin{abstract}
OBJECTIVES: Although an expert review published in 2013 concluded that an association between human papillomavirus (HPV) infection and prostate cancer (PCa) risk had not yet been firmly established, a 2011 systematic review of 14 articles revealed an increased prevalence of HPV-16 DNA in PCa tissues. Another metaanalysis of the related articles is needed to evaluate the potential link between HPV infection and PCa risk.

METHODS: A snowballing search strategy was applied to the previously cited articles in the above-mentioned expert review and systematic review. Additional articles selected for this meta-analysis should fulfill all following inclusion criteria: (a) evaluation of detected HPV-16 DNA in tissue samples and the PCa risk and (b) report of the HPV-16 prevalence in both cancer and control tissues. Estimated summary odds ratios (sOR) with $95 \%$ confidence intervals (CI) were calculated using fixed effect or random-effect models.
\end{abstract}

RESULTS: Hand searching identified 16 new articles. The sOR of the total 30 articles indicated a significant HPV-16 infection-related increase in the PCa risk (sOR, 1.851; 95\% CI, 1.353 to $2.532, \mathrm{I}^{2}=37.82 \%$ ).

CONCLUSIONS: These facts provide additional supportive evidence for a causal role of HPV-16 infection in prostate carcinogenesis. As the PCa incidence rates have increased rapidly in Asian countries, including Korea, during the last several decades, further studies of HPV-related PCa carcinogenesis may be necessary.

KEY WORDS: Prostate neoplasms, Human papillomavirus 16, Risk factor, Meta-analysis, Oncogenic viruses

\section{INTRODUCTION}

Prostate cancer (PCa) represents a major type of cancer in western societies [1], and recently the incidence and mortality rates have been increasing in Asian societies [2-5]. As shown in Figure 1, the PCa incidence rate in Korea has increased continuously during the last decade [6], a finding that has been attributed to an increasingly westernized diet [3-5]. On the other hand, the age group with the highest $\mathrm{PCa}$ incidence rate has changed from the 80 to 84 years group to the 75 to 79 years group (Fig-

Correspondence: Jong-Myon Bae

Department of Preventive Medicine, Jeju National University School of Medicine, 102 Jejudaehak-ro, Jeju 690-756, Korea

Tel: +82-64-755-5567, Fax: +82-64-725-2593, E-mail: jmbae@jejunu.ac.kr

Received: Jan 20, 2015, Accepted: Feb 5, 2015, Published: Feb 11, 2015

This article is available from: http://e-epih.org/

(C) 2015, Korean Society of Epidemiology

(C) This is an open-access article distributed under the terms of the Creative Commons Attribution License (http://creativecommons.org/licenses/by/3.0/), which permits unrestricted use, distribution, and reproduction in any medium, provided the original work is properly cited. ure 1). This pattern can be interpreted as the result of PCa overdiagnosis $[7,8]$.

Non-modifiable factors such as old age, race, or family history are commonly accepted PCa risk factors $[9,10]$. However, epidemiological studies for factors with the potential for preventable intervention, including smoking [11], drinking [12], exercise [13], and diet [14] showed as controversial [15]. Recently, despite a widely publicized systematic review in which a diabetes history was associated with a reduced PCa incidence [16,17], an opposing report stated that diabetes increased the incidence of PCa in Asian populations [18]; therefore, it is necessary to carefully interpret results [19].

On the other hand, chronic recurrent inflammation is known to cause $\mathrm{PCa}$, and theories regarding the etiological mechanism have been established [20-22]. In this context, prostatitis [23] and venereal disease infectivity [24] have been suggested as risk factors for PCa. Given the chance that subject reporting bias could be introduced when measuring the infectivity of venereal disease, however, it was noted that the study results might have been inconsistent [25]. On the other hand, human papil- 


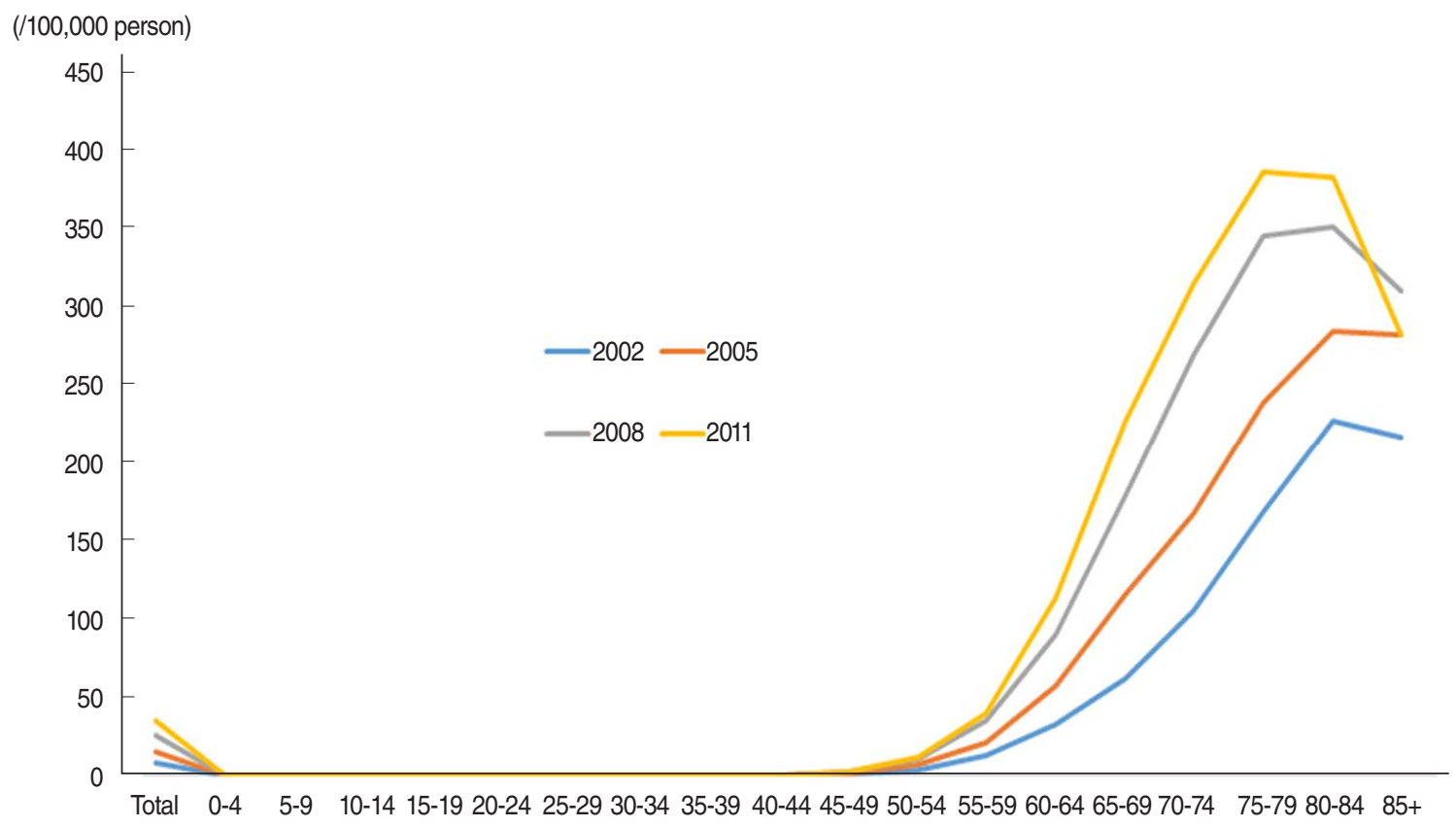

Figure 1. Age-adjusted incidences of prostate cancer in Korean men in 2002, 2005, 2008, and 2011 according to age group.

lomavirus (HPV) infection has been strongly suggested as a risk factor for PCa [26-30]. This suggestion is based on the identification of HPV as a causative risk factor for urogenital system cancers such as cervical cancer and penile cancer [31,32] and the finding that HPV infection as a type of sexually transmitted infection [33,34], causes chronic recurrent inflammation [26]. Moreover, one suggested hypothesis stated that the incidence of breast cancer, which is known to increase along with changes toward a more western lifestyle, is also caused by HPV infection $[35,36]$.

Among the studies conducted to investigate whether HPV infection is a risk factor for PCa, Lin et al. [27] published a systematic review paper (SRP) in 2011 in which a meta-analysis had been applied. The authors concluded that although there was no general association, statistical significance was observed when the analysis was limited to HPV DNA detection of type 16 infection in PCa tissues; therefore, they concluded that the causality remained doubtful. However, a 2013 study by Hrbacek et al. [25] investigated the likelihood that various infections, including HPV, might be risk factors for PCa during the previous three decades; this study concluded, however, that there was no evidence to support an association. However, the EXP study design was an expert review (EXP) without a meta-analysis. As such, although the SRP and EXP reached inconsistent conclusions, the most recent papers cited in the SRP and EXP to demonstrate statistical significance in the detection of HPV type 16 DNA in tissues were published in 2010 and 2011, respectively. Now, in January 2015, it is necessary to perform another meta- analysis including papers newly published since the previous reviews. Thereby, the purpose of the present study was to investigate whether HPV type 16 infection is a risk factor for PCa by performing a meta-analysis using adaptive papers related to HPV type 16 DNA detection in PCa tissues.

\section{MATERIALSAND METHODS}

\section{Searches and selection of related papers}

As the SRP and EXP papers had already been published, it is necessary to set the same selection criteria and fully apply the list of selected subjects to perform another meta-analysis. Thereby, the EXP subject criteria were first maximally reflected for the present study, and the papers were narrowed to case-control studies in which the HPV type 16-related DNA prevalence levels were compared between PCa and control tissues according to the purpose of the study. Finally, papers that did not provide information about type 16 or the number of HPV DNA detection positive tissues were excluded.

In addition, to ensure a more efficient literature search and maximize the use of the subject lists in the SRP and EXP, the snowballing search strategy was applied to manually search for the referred literature in each paper [37]. Therefore, the subjects of the present study were divided into three groups (A, B, and $\mathrm{C}$ groups). First, the A group included 14 papers listed as subjects in the SRP (published in 2011) [38-51]. Second, the B group comprised papers that satisfied the selection criteria but had been 
absent from the A group; these papers were identified from a mutual comparison with the list presented in the EXP (published in 2013). Third, the $C$ group contained papers that satisfied the selection criteria from the list of papers related to each paper in the A and B groups. As papers involving the same study hypothesis are often mutually referent, the search list was created using the list of "Related citations" for each paper as provided by PubMed (National Library of Medicine, USA); subsequently, a manual hand search was performed, followed by the selection of subjects that satisfied the selection criteria [52].

\section{Statistical analysis}

The total numbers of cancer and control tissues and samples with extracted HPV type 16 DNA were identified in the selected papers. Heterogeneity was evaluated using $\mathrm{I}^{2}$ values (\%) [53], and a meta-analysis was performed to calculate the summary odds ratios (sOR) and 95\% confidence intervals (CI) according to the fixed effect model and random effect model, using the OR value of each paper. Furthermore, in consideration of the improved accuracy of HPV DNA detection methods in more recent studies [36,54], a subgroup analysis was performed after the papers were divided depending on the publication before and after the year 2000. Finally, to evaluate any publication bias, the funnel plot symmetry was tested and the Egger regression was applied. The threshold of statistical significance was set at 5\%, and the STATA/SE version 13.0 (StataCorp., College Station, TX, USA) was used for the meta-analysis and creation of the two plots.

\section{RESULTS}

The numbers of detected positive cases in the 30 selected subject papers are presented in Table 1 . Among the 14 papers

Table 1. The subject articles $(n=30)$ in the adaptive meta-analysis for evaluating human papillomavirus 16 infection as a potential risk factor for prostate cancer

\begin{tabular}{|c|c|c|c|c|c|c|c|}
\hline Group & Author & Year & Ref & Case_T & Case_P & Control_T & Control_P \\
\hline A & McNicol \& Dodd & 1991 & 38 & 27 & 14 & 61 & 35 \\
\hline$A$ & Anwar et al. & 1992 & 41 & 68 & 11 & 20 & 0 \\
\hline$A$ & Ibrahim et al. & 1992 & 40 & 24 & 6 & 29 & 2 \\
\hline$A$ & Rotola et al. & 1992 & 39 & 8 & 6 & 17 & 14 \\
\hline A & Tu et al. & 1994 & 42 & 60 & 1 & 1 & 0 \\
\hline A & Moyret-Lalle et al. & 1995 & 43 & 17 & 9 & 22 & 7 \\
\hline A & Terris \& Peehl & 1997 & 44 & 53 & 2 & 78 & 4 \\
\hline A & Noda et al. & 1998 & 45 & 38 & 0 & 71 & 3 \\
\hline A & Serth et al. & 1999 & 46 & 47 & 10 & 37 & 1 \\
\hline A & Carozzi et al. & 2004 & 47 & 26 & 3 & 25 & 0 \\
\hline A & Leiros et al. & 2005 & 48 & 41 & 5 & 30 & 0 \\
\hline$A$ & May et al. & 2008 & 49 & 50 & 10 & 163 & 29 \\
\hline A & Silverstre et al. & 2009 & 50 & 65 & 2 & 6 & 0 \\
\hline A & Aghakhani et al. & 2011 & 51 & 104 & 7 & 104 & 3 \\
\hline B & Masood et al. & 1991 & 64 & 20 & 0 & 20 & 0 \\
\hline B & Dodd et al. & 1993 & 65 & 7 & 3 & 10 & 5 \\
\hline B & Suzuki et al. & 1996 & 66 & 51 & 8 & 51 & 0 \\
\hline B & Wideroff et al. & 1996 & 67 & 56 & 7 & 42 & 4 \\
\hline B & Anderson et al. & 1997 & 68 & 14 & 0 & 10 & 0 \\
\hline B & Strickler et al. & 1998 & 69 & 63 & 0 & 61 & 0 \\
\hline B & Gazzaz \& Mosli & 2009 & 70 & 6 & 0 & 50 & 0 \\
\hline B & Martinez-Fierro et al. & 2010 & 71 & 55 & 0 & 75 & 0 \\
\hline C & McNicol \& Dodd & 1990 & 72 & 4 & 4 & 20 & 15 \\
\hline C & Chen et al. & 2011 & 73 & 51 & 0 & 11 & 0 \\
\hline C & Smelov et al. & 2011 & 74 & 61 & 2 & 14 & 0 \\
\hline C & Tachezy et al. & 2012 & 75 & 51 & 1 & 95 & 11 \\
\hline C & Whitaker et al. & 2013 & 26 & 10 & 0 & 20 & 0 \\
\hline C & Michopoulou et al. & 2014 & 76 & 50 & 2 & 30 & 0 \\
\hline C & Yow et al. & 2014 & 77 & 115 & 0 & 51 & 0 \\
\hline C & Singh et al. & 2015 & 78 & 95 & 30 & 55 & 3 \\
\hline
\end{tabular}

A, selected articles from reference [27]; B, selected articles from a comparison of subjects in reference [27] and reference [25]; C, selected articles via manual searching; Ref, reference number; Case_T, total number in the case group; Case_P, number of positive cases; Control_T, total number in the control group; Control_P, number of positive controls. 
selected from the SRP [38-51], the number of detected DNApositive cases reported in the paper by Terris and Peehl [44] was different from that presented in the SRP, and accordingly this number was corrected.After excluding nine papers [55-63] with no information about HPV type 16 among the 17 papers present in the EXP list but absent from the A group, eight papers [64-71] were added to the B group. Each of these 22 papers and the literature cited in EXP and SRP were manually searched using the list of "Related citations" provided by PubMed; the selection criteria were applied to this search, resulting in the addition of eight new related papers to the $C$ group [26,72-78]. Interestingly, one paper published before 2000 was included in the $\mathrm{C}$ group [72].

Figure 2 and Table 2 present the results of the meta-analysis of a total of 30 papers. As eight papers featured weights of $0 \%$ because of the absence of DNA detection in both cancer and control tissues, the sOR of the fixed effect model in the A group alone was 1.669 (95\% CI, 1.134 to 2.456); this was higher than the sOR (1.54) presented in the SRP. This result was obtained after correcting the values obtained from the paper by Terris and Peehl [44]. When the B and C groups were added to this analysis, although the $\mathrm{I}^{2}$ value increased from $27.78 \%$ to $37.2 \%$, the sOR of the fixed effect model increased to 1.851 (95\% CI, 1.353 to 2.532); the sOR of the random effect model also achieved statistical significance (sOR, 1.719; 95\% CI, 1.037 to 2.848). When a subgroup analysis was performed according to publication year in consideration of variations in the test method accuracy over time, the sOR of the publications after the year 2000 was higher than that of publications before the year 2000, and no change was observed in the statistical significance of the sOR calculated using the fixed effect model (Figure 3). On the other hand, a funnel plot (Figure 4) used to test publication errors was symmetrical, and the Egger regression results also indicated a low likelihood of error $(p=0.537)$.

\section{DISCUSSION}

The results of our adaptive meta-analysis, which added 16 papers to the list analyzed in the previously published SRP, additionally support the hypothesis that HPV-16 infectivity, as determined by DNA detection in tissues, increases the risk of PCa incidence. This introduces a theoretical background on which HPV infectivity must be considered as a risk factor for PCa de-

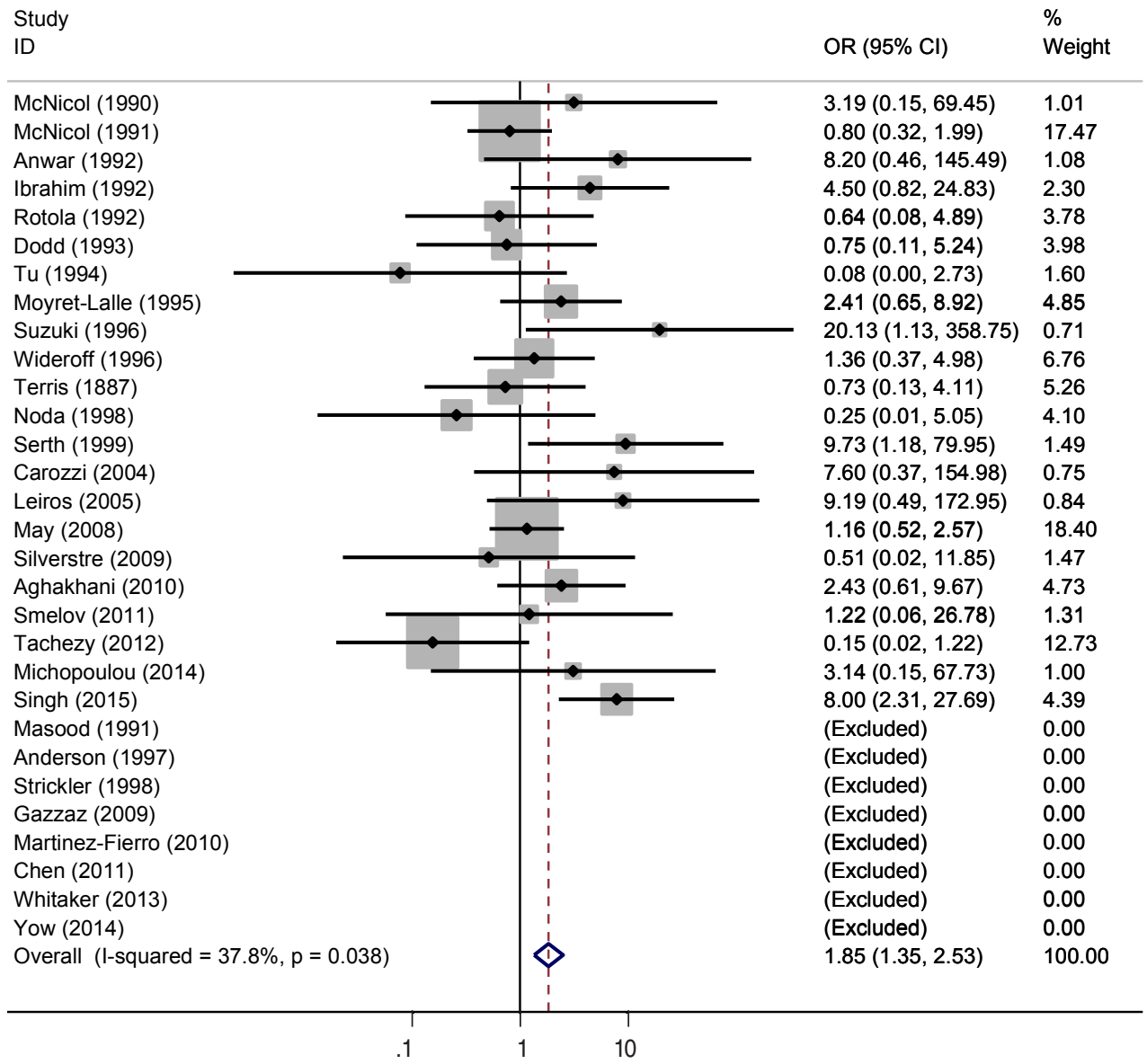

Figure 2. Forest plot of all selected articles $(n=30)$. OR, odds ratio; $\mathrm{Cl}$, confidence interval. 
Table 2. Summary odds ratio (sORs) and 95\% confidence intervals (Cls) from a meta-analysis with subgroup analysis for evaluating human papillomavirus 16 infection as a potential risk factor for prostate cancer

\begin{tabular}{llccc}
\hline Group and subgroup & $\mathrm{n}(\mathrm{df})$ & $\mathrm{I}^{2}$ statistic (\%) & $\mathrm{sOR}$ (Fixed) [95\% Cl] & sOR (Random) [95\% Cl] \\
\hline $\mathrm{A}$ & $14(13)$ & 27.78 & $1.669[1.134,2.456]$ & $1.574[0.906,2.735]$ \\
$\mathrm{A}+\mathrm{B}$ & $22(16)$ & 27.43 & $1.761[1.235,2.509]$ & $1.600[0.968,2.643]$ \\
$\mathrm{A}+\mathrm{B}+\mathrm{C}$ & $30(21)$ & 37.82 & $1.851[1.353,2.532]$ & $1.719[1.037,2.848]$ \\
Publication before 2000 & $16(12)$ & 34.24 & $1.772[1.150,2.729]$ & $1.565[0.820,2.987]$ \\
Publication after 2000 & $14(8)$ & 47.41 & $1.946[1.236,3.064]$ & $1.961[0.812,4.733]$ \\
\hline
\end{tabular}

A, selected articles from reference [27]; B, selected articles from a comparison of subjects in reference [27] and reference [25]; C, selected articles via manual searching. df, degree of freedom; Fixed, fixed effect model; Random, random effect model.

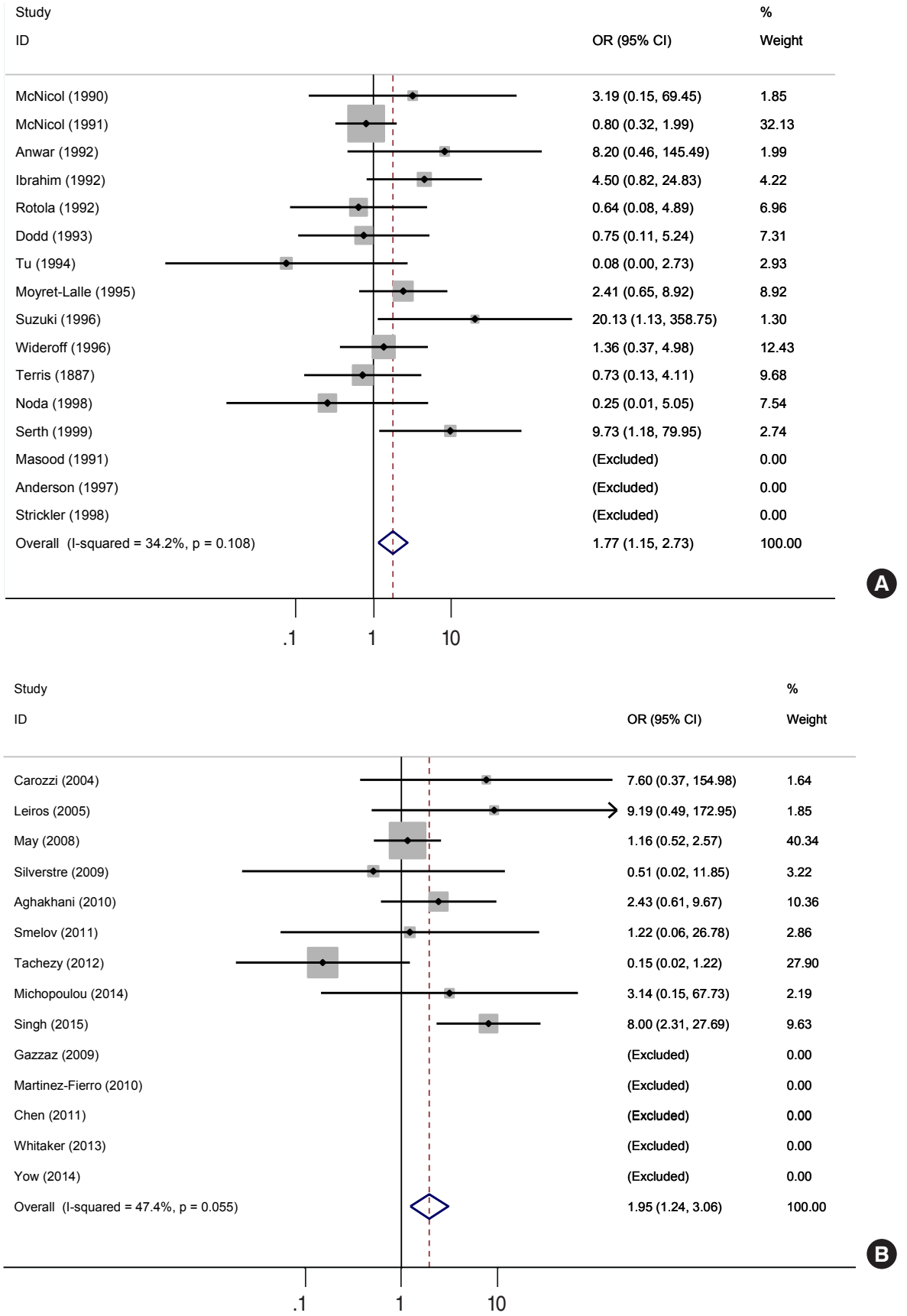

Figure 3. Forest plots of subgroup analyses according to publication year before $(n=16, A)$ and after $2000(n=14, B)$. OR, odds ratio; $\mathrm{Cl}$, confidence interval. 


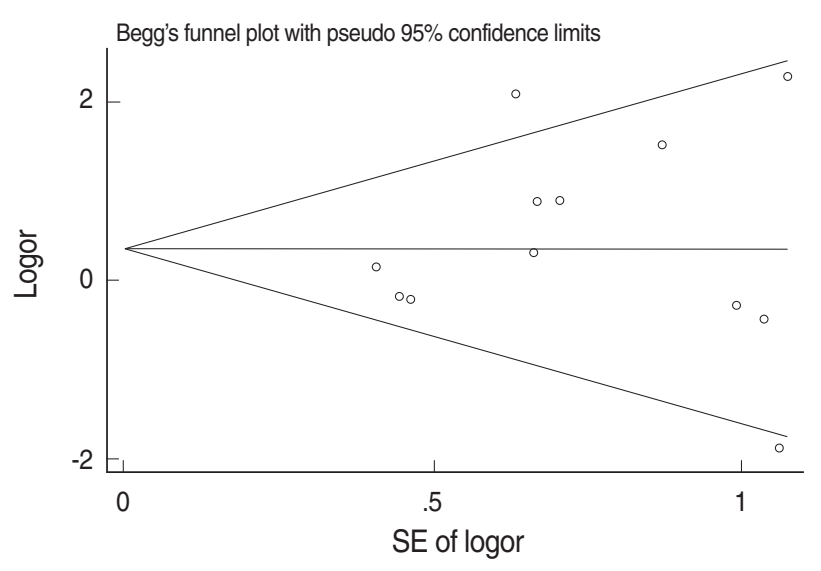

Figure 4. Funnel plot with Egger's test $(t=0.64, p=0.537)$. SE, standard error; logor, log odds ratio.

spite of the controversial conclusions of studies conducted in the past three decades, as shown in the EXP, and indicates the necessity of further studies.

As such, it is necessary to actively conduct research on HPV infectivity as a risk factor for PCa because the findings could lead to the establishment of chemopreventive and immunophylactic strategies to prevent the incidence of related cancers [33]. First, a chemopreventive strategy involving the administration of an anti-inflammatory agent could be devised against chronic and recurrent inflammatory responses resulting from HPV infection [79-81]. This suggestion is supported by a paper published in 2012 [82] in which the administration of aspirin reduced the PCa mortality rate. Second, the findings of such research could lay a theoretical foundation for PCa prevention via HPV vaccination [83] and could provide the additional effect of reduced cervical cancer and breast cancer incidence rates among spouses [36].

The major limitation of the present study is the skip of an online search process required for systematic reviews [52]. However, the present study fully exploited the results of both wide and concentrated searches in the previously published SRP and EXP. In contrast, both time and manpower were expended upon manual searches for each cited paper in the references from both papers to ensure that papers published after SRP and EXP could be secured more efficiently. Using this process, an additional paper [72] that had been excluded despite satisfying the selection criteria was identified, and two other papers $[44,49]$ were identified as present on the SRP list but absent from the EXP list. These findings demonstrate the limitations of a reference search strategy in combination with the existing online search. The snowballing search strategy used in the present study, which is the main search strategy used in narrative review and is difficult to establish [37], is expected to be used effectively for adaptive analyses of preexisting systematic review studies in the future.

Currently, active countermeasures are required for $\mathrm{PCa}$ care because infection is the major etiological agent of cancer worldwide [84-86]; additionally, PCa mostly occurs in older men and Korean society is aging rapidly [87]. Accordingly, it will be necessary to perform active epidemiological studies to reveal causal relationships between $\mathrm{PCa}$ and etiological events, particularly with respect to HPV infectivity [33]. HPV infection can be evaluated either in tissues via DNA detection methods or in sera via serological test methods; the limitations of each method have been well documented in the report by Hrbacek et al. [25]. Recently, the numbers of serological test-based studies have increased, but these are limited because seroconversion occurs in 50-60\% of all HPV-infected people [88]. Review and reflection on these points are therefore recommended when planning a research proposal.

\section{ACKNOWLEDGEMENTS}

This study was supported by the 2014 Scientific Promotion Program funded by Jeju National University.

\section{CONFLICT OF INTEREST}

The author has no conflicts of interest to declare for this study.

\section{SUPPLEMENTARY MATERIAL}

Supplementary material is available at http://www.e-epih.org/.

\section{REFERENCES}

1. Ferlay J, Parkin DM, Steliarova-Foucher E. Estimates of cancer incidence and mortality in Europe in 2008. Eur J Cancer 2010;46:765781.

2. Cullen J, Elsamanoudi S, Brassell SA, Chen Y, Colombo M, Srivastava A, et al. The burden of prostate cancer in Asian nations. J Carcinog 2012;11:7.

3. Zhu Y, Wang HK, Qu YY, Ye DW. Prostate cancer in East Asia: evolving trend over the last decade. Asian J Androl 2015;17:48-57.

4. Namiki M, Akaza H, Lee SE, Song JM, Umbas R, Zhou L, et al. Prostate Cancer Working Group report. Jpn J Clin Oncol 2010;40 Suppl 1:i70-i75.

5. Zhang J, Dhakal IB, Zhao Z, Li L. Trends in mortality from cancers of the breast, colon, prostate, esophagus, and stomach in East Asia: role of nutrition transition. Eur J Cancer Prev 2012;21:480-489.

6. Jung KW, Won YJ, Kong HJ, Oh CM, Lee DH, Lee JS. Cancer statistics in Korea: incidence, mortality, survival, and prevalence in 2011. 
Cancer Res Treat 2014;46:109-123.

7. Hilton WM, Padalecki SS, Ankerst DP, Leach RJ, Thompson IM. Temporal changes in the clinical approach to diagnosing prostate cancer. J Natl Cancer Inst Monogr 2012;2012:162-168.

8. Sandhu GS, Andriole GL. Overdiagnosis of prostate cancer. J Natl Cancer Inst Monogr 2012;2012:146-151.

9. Shavers VL, Underwood W, Moser RP. Race/ethnicity and the perception of the risk of developing prostate cancer. Am J Prev Med 2009; 37:64-67.

10. Van Dong H, Lee AH, Nga NH, Quang N, Le Chuyen V, Binns CW. Epidemiology and prevention of prostate cancer in Vietnam. Asian Pac J Cancer Prev 2014;15:9747-9751.

11. Bae JM, Li ZM, Shin MH, Kim DH, Lee MS, Ahn YO. Cigarette smoking and prostate cancer risk: negative results of the Seoul Male Cancer Cohort Study. Asian Pac J Cancer Prev 2013;14:4667-4669.

12. Middleton Fillmore K, Chikritzhs T, Stockwell T, Bostrom A, Pascal R. Alcohol use and prostate cancer: a meta-analysis. Mol Nutr Food Res 2009;53:240-255.

13. Young-McCaughan S. Potential for prostate cancer prevention through physical activity. World J Urol 2012;30:167-179.

14. Gathirua-Mwangi WG, Zhang J. Dietary factors and risk for advanced prostate cancer. Eur J Cancer Prev 2014;23:96-109.

15. Wolk A. Diet, lifestyle and risk of prostate cancer. Acta Oncol 2005; 44:277-281.

16. Xu H, Mao SH, Ding GX, Ding Q, Jiang HW. Diabetes mellitus reduces prostate cancer risk - no function of age at diagnosis or duration of disease. Asian Pac J Cancer Prev 2013;14:441-447.

17. Bansal D, Bhansali A, Kapil G, Undela K, Tiwari P. Type 2 diabetes and risk of prostate cancer: a meta-analysis of observational studies. Prostate Cancer Prostatic Dis 2013;16:151-158.

18. Long XJ, Lin S, Sun YN, Zheng ZF. Diabetes mellitus and prostate cancer risk in Asian countries: a meta-analysis. Asian Pac J Cancer Prev 2012;13:4097-4100.

19. Zhang F, Yang Y, Skrip L, Hu D, Wang Y, Wong C, et al. Diabetes mellitus and risk of prostate cancer: an updated meta-analysis based on 12 case-control and 25 cohort studies. Acta Diabetol 2012;49 Suppl 1:S235-S246.

20. Sfanos KS, Hempel HA, De Marzo AM. The role of inflammation in prostate cancer. Adv Exp Med Biol 2014;816:153-181.

21. De Marzo AM, Platz EA, Sutcliffe S, Xu J, Grönberg H, Drake CG, et al. Inflammation in prostate carcinogenesis. Nat Rev Cancer 2007; 7:256-269.

22. Elkahwaji JE. The role of inflammatory mediators in the development of prostatic hyperplasia and prostate cancer. Res Rep Urol 2012;5:110.

23. Jiang J, Li J, Yunxia Z, Zhu H, Liu J, Pumill C. The role of prostatitis in prostate cancer: meta-analysis. PLoS One 2013;8:e85179.

24. Caini S, Gandini S, Dudas M, Bremer V, Severi E, Gherasim A. Sexually transmitted infections and prostate cancer risk: a systematic review and meta-analysis. Cancer Epidemiol 2014;38:329-338.

25. Hrbacek J, Urban M, Hamsikova E, Tachezy R, Heracek J. Thirty years of research on infection and prostate cancer: no conclusive evidence for a link. A systematic review. Urol Oncol 2013;31:951-965.

26. Whitaker NJ, Glenn WK, Sahrudin A, Orde MM, Delprado W, Lawson JS. Human papillomavirus and Epstein Barr virus in prostate cancer: Koilocytes indicate potential oncogenic influences of human papillomavirus in prostate cancer. Prostate 2013;73:236-241.

27. Lin Y, Mao Q, Zheng X, Yang K, Chen H, Zhou C, et al. Human papillomavirus 16 or 18 infection and prostate cancer risk: a meta-analysis. Ir J Med Sci 2011;180:497-503.

28. Al Moustafa AE. Involvement of human papillomavirus infections in prostate cancer progression. Med Hypotheses 2008;71:209-211.

29. Al-Maghrabi JA. The role of human papillomavirus infection in prostate cancer. Saudi Med J 2007;28:326-333.

30. Sutcliffe S, Viscidi RP, Till C, Goodman PJ, Hoque AM, Hsing AW, et al. Human papillomavirus types 16, 18, and 31 serostatus and prostate cancer risk in the Prostate Cancer Prevention Trial. Cancer Epidemiol Biomarkers Prev 2010;19:614-618

31. Korodi Z, Dillner J, Jellum E, Lumme S, Hallmans G, Thoresen S, et al. Human papillomavirus 16, 18, and 33 infections and risk of prostate cancer: a Nordic nested case-control study. Cancer Epidemiol Biomarkers Prev 2005;14:2952-2955.

32. Alibek K, Karatayeva N, Bekniyazov I. The role of infectious agents in urogenital cancers. Infect Agent Cancer 2012;7:35.

33. Ramezani A, Banifazl M, Eslamifar A, Aghakhani A. Association between human papillomavirus infection and risk of prostate cancer. Iran J Pathol 2011;6:3-7.

34. Rosenblatt KA, Carter JJ, Iwasaki LM, Galloway DA, Stanford JL. Serologic evidence of human papillomavirus 16 and 18 infections and risk of prostate cancer. Cancer Epidemiol Biomarkers Prev 2003; 12:763-768.

35. Grover PL, Martin FL. The initiation of breast and prostate cancer. Carcinogenesis 2002;23:1095-1102.

36. Bae JM. Two hypotheses of dense breasts and viral infection for explaining incidence of breast cancer by age group in Korean women. Epidemiol Health 2014;36:e2014020.

37. Bae JM. Narrative reviews. Epidemiol Health 2014;36:e2014018.

38. McNicol PJ, Dodd JG. High prevalence of human papillomavirus in prostate tissues. J Urol 1991;145:850-853.

39. Rotola A, Monini P, Di Luca D, Savioli A, Simone R, Secchiero P, et al. Presence and physical state of HPV DNA in prostate and urinarytract tissues. Int J Cancer 1992;52:359-365.

40. Ibrahim GK, Gravitt PE, Dittrich KL, Ibrahim SN, Melhus O, Anderson SM, et al. Detection of human papillomavirus in the prostate by polymerase chain reaction and in situ hybridization. J Urol 1992; 148:1822-1826.

41. Anwar K, Nakakuki K, Shiraishi T, Naiki H, Yatani R, Inuzuka M. Presence of ras oncogene mutations and human papillomavirus DNA in human prostate carcinomas. Cancer Res 1992;52:5991-5996.

42. Tu H, Jacobs SC, Mergner WJ, Kyprianou N. Rare incidence of human papillomavirus types 16 and 18 in primary and metastatic human prostate cancer. Urology 1994;44:726-731.

43. Moyret-Lalle C, Marçais C, Jacquemier J, Moles JP, Daver A, Soret JY, et al. ras, p53 and HPV status in benign and malignant prostate tumors. Int J Cancer 1995;64:124-129.

44. Terris MK, Peehl DM. Human papillomavirus detection by polymerase chain reaction in benign and malignant prostate tissue is dependent on the primer set utilized. Urology 1997;50:150-156.

45. Noda T, Sasagawa T, Dong Y, Fuse H, Namiki M, Inoue M. Detection of human papillomavirus (HPV) DNA in archival specimens of benign prostatic hyperplasia and prostatic cancer using a highly sensitive nested PCR method. Urol Res 1998;26:165-169.

46. Serth J, Panitz F, Paeslack U, Kuczyk MA, Jonas U. Increased levels of human papillomavirus type 16 DNA in a subset of prostate cancers. Cancer Res 1999;59:823-825.

47. Carozzi F, Lombardi FC, Zendron P, Confortini M, Sani C, Bisanzi $\mathrm{S}$, et al. Association of human papillomavirus with prostate cancer: analysis of a consecutive series of prostate biopsies. Int J Biol Markers 2004;19:257-261.

48. Leiros GJ, Galliano SR, Sember ME, Kahn T, Schwarz E, Eiguchi K. Detection of human papillomavirus DNA and p53 codon 72 polymorphism in prostate carcinomas of patients from Argentina. BMC 
Urol 2005;5:15.

49. May M, Kalisch R, Hoschke B, Juretzek T, Wagenlehner F, Brookman-Amissah S, et al. Detection of papillomavirus DNA in the prostate: a virus with underestimated clinical relevance? Urologe A 2008; 47:846-852 (German).

50. Silvestre RV, Leal MF, Demachki S, Nahum MC, Bernardes JG, Rabenhorst SH, et al. Low frequency of human papillomavirus detection in prostate tissue from individuals from Northern Brazil. Mem Inst Oswaldo Cruz 2009; 104:665-667.

51. Aghakhani A, Hamkar R, Parvin M, Ghavami N, Nadri M, Pakfetrat $\mathrm{A}$, et al. The role of human papillomavirus infection in prostate carcinoma. Scand J Infect Dis 2011;43:64-69.

52. Bae JM, Lee EJ, Guyatt G. Citrus fruits intake and prostate cancer risk: a quantitative systematic review. J Prev Med Public Health 2008; 41:159-164.

53. Higgins JP, Thompson SG. Quantifying heterogeneity in a meta-analysis. Stat Med 2002;21:1539-1558.

54. Wang T, Chang P, Wang L, Yao Q, Guo W, Chen J, et al. The role of human papillomavirus infection in breast cancer. Med Oncol 2012; 29:48-55.

55. Effert PJ, Frye RA, Neubauer A, Liu ET, Walther PJ. Human papillomavirus types 16 and 18 are not involved in human prostate carcinogenesis: analysis of archival human prostate cancer specimens by differential polymerase chain reaction. J Urol 1992;147:192-196.

56. Serfling U, Ciancio G, Zhu WY, Leonardi C, Penneys NS. Human papillomavirus and herpes virus DNA are not detected in benign and malignant prostatic tissue using the polymerase chain reaction. J Urol 1992;148:192-194.

57. Sarkar FH, Sakr WA, Li YW, Sreepathi P, Crissman JD. Detection of human papillomavirus (HPV) DNA in human prostatic tissues by polymerase chain reaction (PCR). Prostate 1993;22:171-180.

58. Saad F, Gu K, Jean-Baptiste J, Gauthier J, MesMasson AM. Absence of human papillomavirus sequences in early stage prostate cancer. Can J Urol 1999;6:834-838.

59. Zambrano A, Kalantari M, Simoneau A, Jensen JL, Villarreal LP. Detection of human polyomaviruses and papillomaviruses in prostatic tissue reveals the prostate as a habitat for multiple viral infections. Prostate 2002;53:263-276.

60. Leskinen MJ, Vainionp R, Syrjnen S, Leppilahti M, Marttila T, Kylml $\mathrm{T}$, et al. Herpes simplex virus, cytomegalovirus, and papillomavirus DNA are not found in patients with chronic pelvic pain syndrome undergoing radical prostatectomy for localized prostate cancer. Urology 2003;61:397-401.

61. Bergh J, Marklund I, Gustavsson C, Wiklund F, Grönberg H, Allard A, et al. No link between viral findings in the prostate and subsequent cancer development. Br J Cancer 2007;96:137-139.

62. Balis V, Sourvinos G, Soulitzis N, Giannikaki E, Sofras F, Spandidos DA. Prevalence of BK virus and human papillomavirus in human prostate cancer. Int J Biol Markers 2007;22:245-251.

63. Sfanos KS, Sauvageot J, Fedor HL, Dick JD, De Marzo AM, Isaacs WB. A molecular analysis of prokaryotic and viral DNA sequences in prostate tissue from patients with prostate cancer indicates the presence of multiple and diverse microorganisms. Prostate 2008;68:306320.

64. Masood S, Rhatigan RM, Powell S, Thompson J, Rodenroth N. Human papillomavirus in prostatic cancer: no evidence found by in situ DNA hybridization. South Med J 1991;84:235-236.

65. Dodd JG, Paraskevas M, McNicol PJ. Detection of human papillomavirus 16 transcription in human prostate tissue. J Urol 1993;149: 400-402.

66. Suzuki H, Komiya A, Aida S, Ito H, Yatani R, Shimazaki J. Detec- tion of human papillomavirus DNA and p53 gene mutations in human prostate cancer. Prostate 1996;28:318-324.

67. Wideroff L, Schottenfeld D, Carey TE, Beals T, Fu G, Sakr W, et al. Human papillomavirus DNA in malignant and hyperplastic prostate tissue of black and white males. Prostate 1996;28:117-123.

68. Anderson M, Handley J, Hopwood L, Murant S, Stower M, Maitland NJ. Analysis of prostate tissue DNA for the presence of human papillomavirus by polymerase chain reaction, cloning, and automated sequencing. J Med Virol 1997;52:8-13.

69. Strickler HD, Burk R, Shah K, Viscidi R, Jackson A, Pizza G, et al. A multifaceted study of human papillomavirus and prostate carcinoma. Cancer 1998;82:1118-1125.

70. Gazzaz FS, Mosli HA. Lack of detection of human papillomavirus infection by hybridization test in prostatic biopsies. Saudi Med J 2009; 30:633-637.

71. Martinez-Fierro ML, Leach RJ, Gomez-Guerra LS, Garza-Guajardo $\mathrm{R}$, Johnson-Pais T, Beuten J, et al. Identification of viral infections in the prostate and evaluation of their association with cancer. BMC Cancer 2010;10:326.

72. McNicol PJ, Dodd JG. Detection of human papillomavirus DNA in prostate gland tissue by using the polymerase chain reaction amplification assay. J Clin Microbiol 1990;28:409-412.

73. Chen AC, Waterboer T, Keleher A, Morrison B, Jindal S, McMillan $\mathrm{D}$, et al. Human papillomavirus in benign prostatic hyperplasia and prostatic adenocarcinoma patients. Pathol Oncol Res 2011;17:613617.

74. Smelov V, van Moorselaar J, Startsev V, Smelova N, Grigorovich E, Meijer C, et al. No high-risk human papillomavirus infection in prostate cancer tissues. Scand J Infect Dis 2011;43:399-400.

75. Tachezy R, Hrbacek J, Heracek J, Salakova M, Smahelova J, Ludvikova $\mathrm{V}$, et al. HPV persistence and its oncogenic role in prostate tumors. J Med Virol 2012;84:1636-1645.

76. Michopoulou V, Derdas SP, Symvoulakis E, Mourmouras N, Nomikos A, Delakas D, et al. Detection of human papillomavirus (HPV) DNA prevalence and p53 codon 72 (Arg72Pro) polymorphism in prostate cancer in a Greek group of patients. Tumour Biol 2014;35:1276512773.

77. Yow MA, Tabrizi SN, Severi G, Bolton DM, Pedersen J, Longano A, et al. Detection of infectious organisms in archival prostate cancer tissues. BMC Cancer 2014;14:579.

78. Singh N, Hussain S, Kakkar N, Singh SK, Sobti RC, Bharadwaj M. Implication of high risk Human papillomavirus HR-HPV infection in prostate cancer in Indian population- A pioneering case-control analysis. Sci Rep 2015;5:7822.

79. Roxburgh CS, McMillan DC. Cancer and systemic inflammation: treat the tumour and treat the host. Br J Cancer 2014;110:1409-1412.

80. Chung JI. Prevention of prostate cancer. J Korean Med Assoc 2010; 53:135-141 (Korean).

81. Bardia A, Platz EA, Yegnasubramanian S, De Marzo AM, Nelson WG. Anti-inflammatory drugs, antioxidants, and prostate cancer prevention. Curr Opin Pharmacol 2009;9:419-426.

82. La Vecchia C, Bosetti C. Urological cancer: Aspirin and the risk of prostate cancer mortality. Nat Rev Clin Oncol 2012;9:616-617.

83. Castellsagué X, Schneider A, Kaufmann AM, Bosch FX. HPV vaccination against cervical cancer in women above 25 years of age: key considerations and current perspectives. Gynecol Oncol 2009;115: S15-S23.

84. Vedham V, Divi RL, Starks VL, Verma M. Multiple infections and cancer: implications in epidemiology. Technol Cancer Res Treat 2014; 13:177-194.

85. Sankaranarayanan R, Ramadas K, Qiao YL. Managing the changing 
burden of cancer in Asia. BMC Med 2014;12:3.

86. Park S, Bae J, Nam BH, Yoo KY. Aetiology of cancer in Asia. Asian Pac J Cancer Prev 2008;9:371-380.

87. Colón-López V, Ortiz AP, Palefsky J. Burden of human papillomavirus infection and related comorbidities in men: implications for re- search, disease prevention and health promotion among Hispanic men. P R Health Sci J 2010;29:232-240.

88. Konya J, Dillner J. Immunity to oncogenic human papillomaviruses. Adv Cancer Res 2001;82:205-238. 